\title{
DETERMINANTS OF MSME COMPETITIVENESS IN ACEH PROVINCE
}

\author{
Chairil Akhyar ${ }^{1}$, Ikramuddin ${ }^{2}$, Em. Yusuf Iis $^{3}$, Mariyudi ${ }^{4}$ \\ ${ }^{1,2,3,4}$ Departement of Management, Faculty of Economic and Business Universitas Malikussaleh \\ Correspondence Author: ' $\underline{\text { ikramuddin@ unimal.ac.id, }}$
}

\begin{abstract}
Micro, Small and Medium Enterprises are one of the drivers of national economic growth, because of their ability to absorb workers equal to $95 \%$ with a total investment of $60.4 \%$. This study aims to examine the effect of capital capability, empowerment, and product innovation on the competitiveness of micro, small and medium enterprises. And the role of product innovation as a mediating variable in the indirect influence between the coaching program and capital on the competitiveness of micro, small and medium enterprises in Aceh. Study designs a Quantitative Research. This research was conducted on micro, small and medium enterprises (MSMEs) in Aceh Province, Indonesia. The population in this study were micro, small and medium enterprises (MSMEs). The research sample was determined by purposive sampling, with a sample size of 272 SMEs. While the data analysis tool usesStructural Equation Modeling (SEM) Amos to test the effect between exogenous variables and endogenous variables. Pdirect effect test found that capital has no effect on product innovation by -0.035, P-Value 0.754 (Not supported H1). Empowerment has a significant effect on product innovation by 0.249, p-value 0.030 (Supported H2). Capital has a significant effect on the competitiveness of SMEs by 0.220, p-vale 0.014 (Supported H3). Empowerment has a significant effect on MSME competitiveness by 0.542, and p-value 0.000 (Supported H4), and product innovation has a significant effect on MSME competitiveness by 0.274 and p-value 0.000 (supported H5). To test the indirect effect using the Sobel test calculator, it was found that product innovation variables were able to partially mediate the relationship between capital and empowerment on the competitiveness of SMEs. The results of the study indicate that the Empowerment and Product Innovation variables have a significant effect on the competitiveness of MSMEs both directly and indirectly, except for the Capital variable which is found to be insignificant to Product Innovation. Finally, the researcher concludes that the competitiveness of micro, small and medium enterprises in Aceh is determined by the factors of capital capability, empowerment program and product innovation.
\end{abstract}

Keywords: Capital Ability, Development, Product innovation, Competitive advantage, SMEs.

\section{INTRODUCTION}

Indonesia is currently entering the demographic bonus phase, where the proportion of young people currently amounting to more than 25 percent of the total of about 270 million Indonesians combined with 59.2 million Micro, Small, Medium Enterprises (MSMEs) units that make a big contribution to the National Gross Domestic Product (GDP) (Central Bureau of Statistics (BPS), 2020). The high rate of population growth is not proportional to the high growth of entrepreneurship. Indonesia's entrepreneurial growth until 2020 is $3.47 \%$ or Indonesia is in position 94 out of 137 countries in the world(Adam, Ibrahim, Ikramuddin, \& Syahputra, 2020). According to the magazine(CEOWORLD. Magazine's, 2021), Entrepreneurship Index Indonesia in 2021 ranks 45th as the most entrepreneurial country in the world out of 100 surveyed countries, with the ability to access capital of 226.52 and openness for business of 0.44 percent. In addition, for the category of the most innovative country, Indonesia is ranked 3.95. This percentage is much smaller than other Asean countries. On average, developed countries have an entrepreneurial growth rate of 14 percent.

The low growth of entrepreneurship in Indonesia is influenced by several weaknesses that can affect the competitiveness and productivity of small and medium enterprises. The concept of 
competitiveness is directly related to sustainable competitive advantage and business competitiveness in general is often conceptualized as a business capacity to increase efficiency in the use of resources and business capabilities to create value-added competencies.(Lafuente, Szerb, \& Rideg, 2020). Some of the weaknesses of MSMEs in Indonesia lie in Empowerment, the quality of Human resources, in the fields of management, organization, technology, capital, risk management, operational and technical in the field, and limited market access, licensing constraints, as well as non-technical costs in the field which are difficult. to be avoided. In addition, the innovation and creativity of MSME managers is also very low, so that MSME products are difficult to compete in the market. Supporting this statement, there is a study conducted by the State Ministry of KUMKM which states that MSMEs experiencing business difficulties are 72.47 percent, the remaining 27.53 percent have no problems.(Kholidah \& Hakim, 2018).

Several empirical studies have found that the competitiveness of MSMEs is influenced by many factors, especially in Aceh Province, especially during the current Covid 19 Pandemic, among the factors that cause the low competitiveness of MSMEs is the lack of guidance for MSME actors. (Dixon \& Pusparini, 2020; Susana, Darsono, \& Andarwati, 2020), product innovation (Ashoor, 2021; Christa \& Kristinae, 2021; Sulistyo \& Ayuni, 2020), access to capital (Abbas, 2018; Munifatik, Askandar, \& Mahsuni, 2018), marketing orientation (Ali, Hilman, \& Gorondutse, 2020; Puspaningrum, 2020; Rajadurai, Zahari, Esa, Bathmanathan, \& Isaac, 2021). The novelty of this advanced research lies in the selection of methods and processes for designing a model to increase the competitiveness of Micro, Small and Medium Enterprises through a review of capital, product innovation and marketing orientation. The selection of these methods and concepts is expected to provide the right solution for solving the problem of the low competitiveness and performance of MSMEs in the new normal era in Aceh Province. Based on this description, this study will re-examine the factors that affect the competitiveness of small and medium micro enterprises in Aceh.

\section{IMPLEMENTATION METHOD}

\subsection{MSME Empowerment}

MSME empowerment is an effort to build power (community of MSME actors) by encouraging, motivating, and raising awareness of their potential and trying to develop MSMEs. (Nyoman, Suryadinatha Oka, \& Mahaputr, 2017). There are five main missions in empowerment, namely (1) awareness; (2) organizing; (3) companion cadre; (4) technical support, and (5) system management.

\subsection{Capital}

Capital is the funds used for business sustainability (Aprilia \& Jasmine, 2021). Capital is an investment in short-term assets or investment in current assets. Working capital can be categorized into two, namely gross working capital and net working capital.(Abbas, 2018). Gross working capital is total current assets, and net working capital is total current assets minus current liabilities. Including intellectual capital, social capital and relational capital(Gjergji, Vena, Sciascia, \& Cortesi, 2021). The size of the business capital used has an impact on the success or failure of a business(Junedi \& Arumsari, 2021).

\subsection{Product Innovation}

Innovation can be defined as the practical development and improvement of an initial invention into a usable technique (process innovation) or product (product innovation). (Rashid \& Indah, 2018). Next(Zhang, Fan, Zhang, Wang, \& Fan, 2021)said that Innovation in business is the process of applying new ideas or inventions into goods or services that create value that customers will pay for. Innovation capability is the implementation and creation of technology applied to new systems, policies, programs, products, processes and services for the organization(Sulistyo \& Ayuni, 2020). Product innovation is carried out to maintain a competitive advantage in a constantly 
changing business environment, and a superior business is a business that is at the forefront of innovation. Product innovation can encourage manufacturers to proactively obtain customer ratings of products and increase customer knowledge about new functionality and features of products, to gain a competitive advantage.(Al-Abdallah \& Al-Salim, 2021).

\subsection{Competitiveness of SMEs}

In today's increasingly complex global economy, business organizations are increasingly seeing that innovation is an important factor to stay competitive in their industry and to change business strategies. (Afraz, Bhatti, Ferraris, \& Couturier, 2021). Competitiveness is the concept of comparing the ability and performance of companies, sub-sectors or countries to sell and supply goods and or services provided in the market.(Winarti, Purnomo, \& Akhmad, 2019; Zhang et al., 2021). Identification of competitiveness includes: 1) Types of products offered 2) The size of the market controlled 3) Identification of opportunities and threats 4) Identification of strengths and weaknesses(Munifatik et al., 2018). The increasing competitiveness of MSMEs will directly or indirectly affect the performance of MSMEs. according to(Adam, Ibrahim, Syahputra, \& Ikramuddin, 2020; Ikramuddin, Adam, Sofyan, \& Faisal, 2018) increasing customer loyalty to products and brands will improve business performance.

\subsection{Micro Small and Medium Enterprises}

Many definitions of SME are used around the world. Definition of SMEs according to(Oláh, Virglerova, Popp, Kliestikova, \& Kovács, 2019)MSMEs are based on the number of employees, turnover, and the total value of the balance sheet. MSMEs have several positive characteristics related to their size (a higher degree of flexibility and faster strategy development). In the Indonesian economy, MSMEs are the business group that has the largest number and is proven to be resistant to various kinds of shocks from the economic crisis. The criteria for businesses that are included in Micro, Small and Medium Enterprises have been regulated in the legal umbrella.

Based on the Decree of the Minister of Finance No. 316/KMK.016/1994 dated 27 June 1994, small businesses are defined as individuals. Criteria for Micro, Small and Medium Enterprises (MSMEs):

a. The criteria for Micro, Small and Medium Enterprises (MSMEs) according to Law Number 20 of 2008 are classified based on the number of assets and turnover owned by a business.

1) Micro Enterprises Max. 50 Million Max. 300 Million.

2) Small Business $>50$ Million - 500 Million > 300 Million - 2.5 Billion

3) Medium Enterprises > 500 Million - 10 Billion > 2.5 Billion - 50 Billion

b. Criteria for Small and Medium Enterprises Based on Development.

Apart from being based on the Act, from the point of view of its development (Sedyastuti, 2018) grouping MSMEs into several criteria, namely:

a. Livelihood Activities, is a Small and Medium Enterprise that is used as a job opportunity to earn a living, which is more commonly known as the informal sector. An example is a street vendor.

b. Micro Enterprise, is a Small and Medium Enterprise that has the nature of craftsmen but does not yet have the nature of entrepreneurship.

c. Small Dynamic Enterprise, is a Small and Medium Enterprise that already has an entrepreneurial spirit and is able to accept subcontract and export work. 


\subsection{Research Framework}

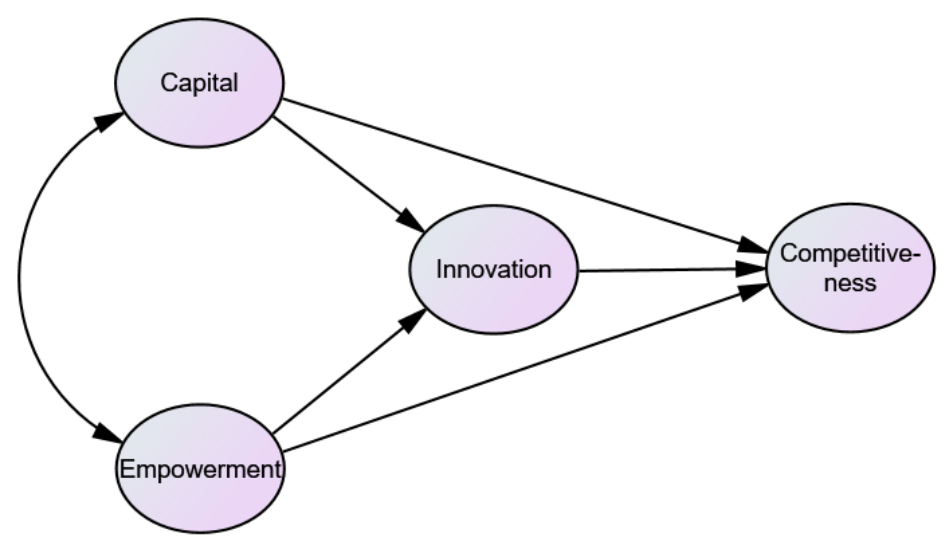

Figure 1 Research Framework

\subsection{Research Hypotheses}

Based on the description of the empirical study, several hypotheses were proposed in this study, namely:

H1: Capital has a significant effect on MSME product innovation in Aceh.

$\mathrm{H} 2$ : Coaching has a significant effect on MSME product innovation in Aceh.

H3: Capital has a significant effect on the competitiveness of MSMEs in Aceh.

H4: Coaching has a significant effect on the competitiveness of MSMEs in Aceh.

H5: Product innovation has a significant effect on the competitiveness of MSMEs in Aceh.

H6: Product innovation can mediate the effect of capital variables on the competitiveness of MSMEs in Aceh.

H7: Product innovation can mediate the influence of the coaching variable on the competitiveness of MSMEs in Aceh.

\subsection{Research Methodology}

This type of research is causality associative research, namely research that aims to analyze one variable with other variables or the effect of exogenous variables on endogenous variables. The sample in this study was 272 MSME actors in North Aceh Regency. Determination of the number of samples/research data using theory(Joseph F. Hair, Black, Babin, \& Anderson, 2018). Next(Joseph F. Hair et al., 2018)said that determining the number of samples in a large population can be done by multiplying the number of research parameters by 5-10 times the number of research parameters. The research location is North Aceh Regency, Aceh Province, Indonesia.The statistical model used to analyze the data collected through questionnaires is a structural analysis tool using Amos Structural Equation Modeling (SEM).

\section{RESULTS AND DISCUSSION}

\subsection{Sample Demographic Statistics}

Table 1 describes the condition of the respondents' characteristics. Where most of the respondents in this study were male respondents 250 people (91.9\%), the average age was between 40 and 50 years $(46.0 \%)$, married as many as 226 people $(83.0 \%)$, and have an average education level as Diploma and Bachelor level respectively (40.0\%), with work experience or length of business 10 to 15 years as many as 134 people (49.0\%). 


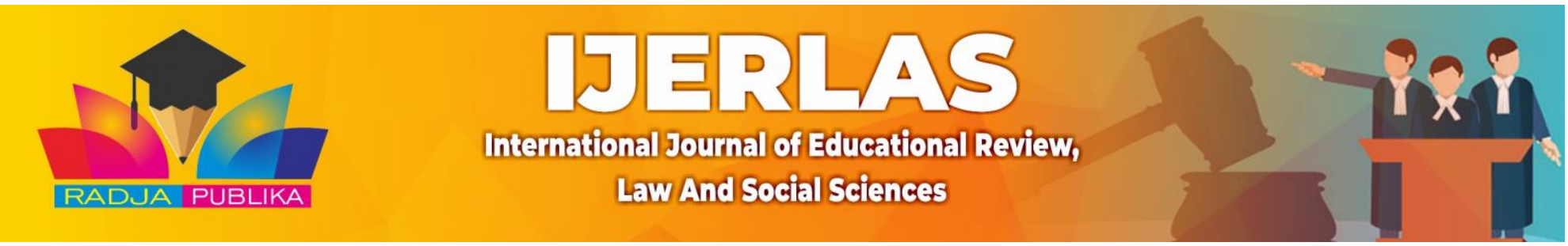

Table 1 Sample Demographic Statistics

\begin{tabular}{lll}
\hline Demographic Characteristics & Frequency & Percentage \\
\hline Gender & & \\
Male & 250 & $91.9 \%$ \\
female & 22 & $8.1 \%$ \\
Total & 272 & $100 \%$ \\
Age & & \\
20-30 Years & 20 & $8.0 \%$ \\
30-40 Years & 88 & $32.0 \%$ \\
40-50 Years & 126 & $46.0 \%$ \\
>50 Years & 38 & $14.0 \%$ \\
Total & 272 & $100 \%$ \\
Marital Status & & \\
Single & 32 & $12.0 \%$ \\
Married & 226 & $83.0 \%$ \\
Window/window & 14 & $5.0 \%$ \\
Total & 272 & $100 \%$ \\
Level of Education & & \\
High School & 46 & $17.0 \%$ \\
Diploma & 110 & $40.0 \%$ \\
University Degree & 108 & $40.0 \%$ \\
Postgraduate Degree & 8 & $3.0 \%$ \\
Total & 272 & $100 \%$ \\
Work experience (length of work) & & \\
< 5 years & 16 & $6.0 \%$ \\
5-10 years & 76 & $28.0 \%$ \\
10-15 years & 134 & $17.0 \%$ \\
15-20 years & 46 & $100 \%$ \\
Total & 272 & \\
\hline Source: Data is processed using SPSS, & 2021 \\
\hline
\end{tabular}

Source: Data is processed using SPSS, 2021

\subsection{Reliability and Validity of the Measurement Model}

The results of the statistical model measurements are summarized in Table 2. The CFA procedure through SEM was carried out to evaluate the reliability and validity of the measurement instrument. All constructs proved reliable, because the Cronbach value and the construct reliability value were greater than 0.70 , as recommended(Joseph F. Hair et al., 2018). The validity of the instrument was measured using a Likert scale (scale 1-5). Discriminate Validity confirmed with Average Variance Extracted (AVE), as recommended(Malhotra, Lopes, \& Veiga, 2014). The AVE value for each construct is greater than the recommended shared variance value, indicating discriminant validity. AVE value above 0.50 indicates convergent validity. The measurement model also shows statistical fit (see Table 3 ) with degrees of freedom $(\chi 2 / \mathrm{df}=1.227)$, TuckerLewis index $(\mathrm{TLI}=0.986)$, comparative fit index $(\mathrm{CFI}=0.990)$ and root mean square error of approximation $(\mathrm{RMSEA}=0.029)$ and confirm construct validity. Thus, it can be concluded that the model fit statistically.

Table 2 Reliability and Convergent validity and Discriminant validity Result Summary

\begin{tabular}{lccccc}
\hline $\begin{array}{c}\text { Construction and } \\
\text { items }\end{array}$ & $\begin{array}{c}\text { Factor } \\
\text { loading }\end{array}$ & $\begin{array}{c}\text { Composite } \\
\text { Reliability }\end{array}$ & AVE & $\begin{array}{c}\text { Shared } \\
\text { Variance }\end{array}$ & $\begin{array}{c}\text { Cronbach } \\
\text { Alpha }\end{array}$ \\
\hline $\begin{array}{l}\text { Empowerment } \\
\text { em1 }\end{array}$ & 0.735 & & & & \\
em2 & 0.761 & 0.828 & 0.547 & 0.288 & 0.828 \\
em3 & 0.766 & & & & \\
em4 & 0.695 & & & & \\
Capital Access & 0.709 & 0.816 & 0.527 & 0.299 & 0.747 \\
ca1 & & & & & \\
\end{tabular}


Determinants Of MSME Competitiveness In Aceh Province

Chairil Akhyar, Ikramuddin, Em. Yusuf Iis, Mariyudi

\begin{tabular}{llllll} 
ca2 & 0.676 & & & & \\
ca3 & 0.711 & & & \\
ca7 & 0.801 & & & & \\
Innovative Products & & & & \\
in1 & 0.712 & & & \\
in2 & 0.830 & & & \\
in3 & 0.650 & 0.854 & 0.541 & & \\
in4 & 0.689 & & & \\
in5 & 0.782 & & & \\
Competitive & & & & \\
Advantage & & & & \\
ca1 & 0.660 & & & \\
ca2 & 0.650 & 0.847 & & \\
ca3 & 0.680 & & & \\
ca4 & 0.844 & & & \\
ca5 & 0.781 & & & \\
\hline Source: Data is processed using Amos, 202 & & &
\end{tabular}

Table 3 Goodness of fit Indices in the measurement model

\begin{tabular}{llll}
\hline $\begin{array}{c}\text { Selected } \\
\text { Indices }\end{array}$ & $\begin{array}{c}\text { Result } \\
\text { Outcome }\end{array}$ & \multicolumn{1}{c}{ Acceptable Level of Fit } & $\begin{array}{c}\text { Source for Suggested } \\
\text { Cut off Limits }\end{array}$ \\
\hline Normed 2/df & 1,227 & $(\chi 2 / \mathrm{df}) 3 ;$ 5 Sometimes Permissible & \\
P-Value & 0.134 & $\mathrm{P}>0.05$ & \\
TLI & 0.986 & TLI $>0.90$ & (Joseph F. Hair et al., \\
CFI & 0.990 & CFI $>0.90$ & 2018) \& (Malhotra et \\
GFI & 0.967 & GFI $>0.95$ & al., 2014) \\
AGFI & 0.946 & AGFI $>0.95$ & \\
RMSEA & 0.029 & RMSEA $<0.05$ good; 0.05 to 0.10 & \\
\multicolumn{2}{ll}{ Source: Data is processed using Amos, 2021 } &
\end{tabular}

\subsection{Structural Model Analysis}

Structural models were used to assess the relationship between constructs and to validate the hypotheses of this study (H1-H5) formulated earlier. The conceptual framework model (see fig 1) is tested with toolsStructural Equation Modeling (SEM) Amos, with maximum likelihood estimates of the model parameters. These parameters include standardized regression weights $(\beta)$ and significance values (P-Value) of the different paths. For the results of the analysis usingStructural Equation Modeling (SEM) Amos, presented in table 4 and in Figure 2. Table 4 and Figure 2 show the coefficients of standardized regression weights for the direct relationship between research constructs, and confirm the hypothetical relationship.

First. The results of the study found a positive and insignificant relationship between the ability of venture capital to product innovation $(\beta=-0.035, \mathrm{t}=0.313, \mathrm{p}=0.754)$. This result is inconsistent with $\mathrm{H} 1$ and the hypothesis is rejected. This finding validates previous research conducted by(Purwati, Budiyanto, Suhermin, \& Hamzah, 2020)(Le \& Ikram, 2021) who found that explicitly innovation could not increase the competitiveness of MSMEs.

Second.The test results determined that the development program for MSMEs had a significant effect on product innovation $(\beta=0.249, \mathrm{t}=2.169, \mathrm{p}=0.000)$. This result is consistent with $\mathrm{H} 2$, and the hypothesis is accepted. This coaching includes management coaching, training for workers, business management training and coaching MSME product marketing. The development program through the development of business organizations can not only improve business performance but also be able to innovate in the management of business capital(El Chaarani, Vrontis, El Nemar, \& El Abiad, 2021).

Third. The ability of working capital has a significant effect on the competitiveness of MSMEs, with a value $(\beta=0.220, \mathrm{t}=2.446, \mathrm{p}=0.014)$, which states that they accept H3. Business 
capital capabilities include funding capital capabilities, including access to business credit funds for MSME entrepreneurs, intellectual capital capabilities, social capital capabilities and relational capital capabilities.(Gjergji et al., 2021). In previous research(Ren \& Song, 2021), identified that competitiveness and business performance in China are influenced by intellectual capital (measured by manually built human capital and organizational capital) and corporate innovation of companies listed in China.

Fourth, the MSME empowerment program has a significant effect on the competitiveness of MSMEs, with a coefficient value of $(\beta=0.542, t=5.193, p=0.000)$. This result is consistent with statement $\mathrm{H} 4$, that is, the hypothesis is accepted. The results of this study are in line with(Herman \& Armadi, 2021; N Ntwiga, Muchara, \& Kiriria, 2021), which illustrates that employee empowerment programs can significantly increase competitive advantage. Employees who get empowerment will be more responsive, have a good attitude, are reliable, and have a high sense of empathy.

Fifth.Product innovation has a significant effect on the competitiveness of SMEs by $(\beta=$ $0.274, \mathrm{t}=3.389, \mathrm{p}=0.000$ ), which states that this result is consistent with $\mathrm{H} 5$, and the hypothesis is accepted. This innovation includes innovation in business ideas and ideas, product innovation, innovation in packaging, innovation in marketing activities. The results of this study validate the opinion(Ryu, Baek, \& Yoon, 2021), that the innovation factor can directly and indirectly increase competitiveness which in turn has an impact on the high performance of MSMEs. Next(Christa \& Kristinae, 2021; Omerzel \& Jurdanab, 2016)said innovation can improve business performance by increasing competitiveness. Innovations (including incremental and radical innovations) are also identified in increasing business competitiveness during the Covid era(Christa \& Kristinae, 2021).

Then, as shown in Table 3, the structural model is also statistically fit, which is indicated by $(\chi 2 / \mathrm{df}=1.227$, TLI $=0.986, \mathrm{CFI}=0.990$, and RMSEA $=0.029)$, so it can be concluded that the research model supports the data, as shown. suggested by(Joseph F. Hair et al., 2018) and (Malhotra et al., 2014).

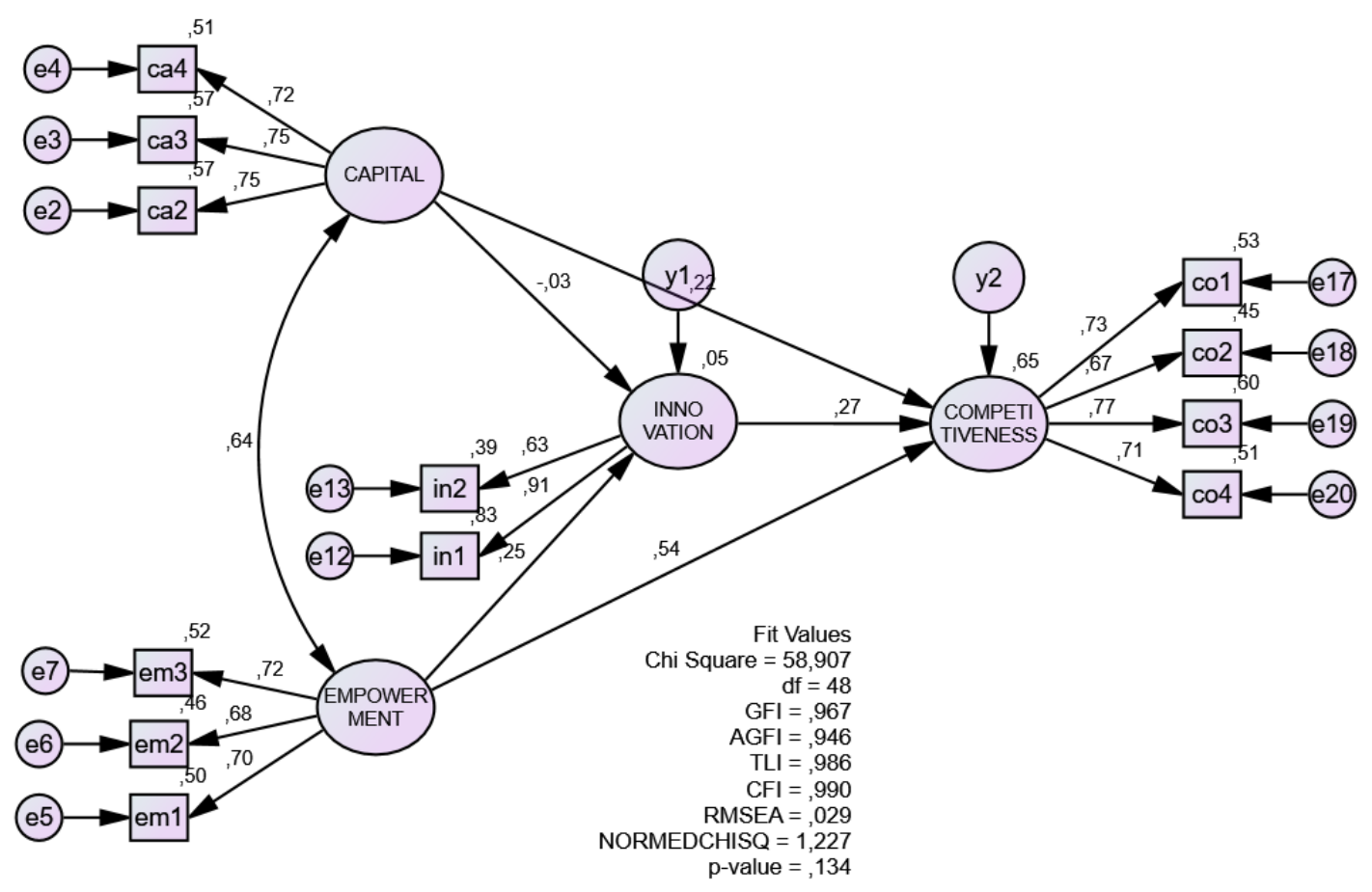

Figure 2 Structural Model for SMEs Sompetitiveness 
Determinants Of MSME Competitiveness In Aceh Province

Chairil Akhyar, Ikramuddin, Em. Yusuf Iis, Mariyudi

Table 4 Hypothesis testing and results for the structural model

\begin{tabular}{lcccc}
\hline \multicolumn{1}{c}{ Hypotheses } & $\begin{array}{c}\text { Direct path } \\
\text { estimates }(\boldsymbol{\beta})\end{array}$ & $\begin{array}{c}\text { t- } \\
\text { Statistics }\end{array}$ & $\begin{array}{c}\text { Probability } \\
\text { value }(\mathbf{P})\end{array}$ & $\begin{array}{c}\text { Hypotheses } \\
\text { result (p } \\
\mathbf{0 . 0 5}\end{array}$ \\
\hline H1 : Capital Innovative & -0.035 & -0.313 & 0.754 & Not supported \\
H2: Empowerment Innovative & 0.249 & 2,169 & 0.030 & Supported \\
H3 : Capital Competitive & 0.220 & 2,446 & 0.014 & Supported \\
H4 : Empowerment Competitive & 0.542 & 5,193 & 0.000 & Supported \\
H5 : Innovative Competitive & 0.274 & 3,389 & 0.000 & Supported \\
\hline Source: Data is processed using Amos, 2021 & & & &
\end{tabular}

Source: Data is processed using Amos, 2021

Based on Figures 3 and 4, testing the mediating effect to validate H6 and H7 using the mediating effect assessment criteria(Baron \& Kenny, 1986). Theoretical assessment results(Baron \& Kenny, 1986), to explain the role of mediation, then all paths a, b, and c must have a value significantly lower than alpha 0.05 , and a value of $c^{\prime}$ greater than 0.05 . For H6 (see fig.3), the significance value of path a was found to be greater than 0.05 (not significant), it was concluded that the first mediating effect model of the product innovation variable did not mediate the relationship between venture capital capabilities and the competitiveness of SMEs. To prove the statement $\mathrm{H} 7$ (see fig.4), the significance value of paths a, b and c was found to be less than 0.05 (significant) and the significance value of $c^{\prime}$ was $0.136(0.136>0.05)$, it was concluded that the product innovation variable mediates well the relationship between the coaching program and the competitiveness of MSMEs in Aceh Province. The findings in this study are in line with research(Christa \& Kristinae, 2021) which explains that innovation has a mediating effect on the relationship between intellectual capital and the achievement of business competitive advantage.

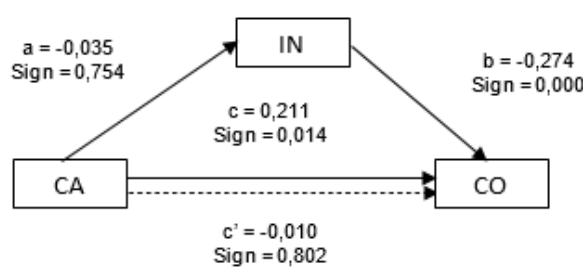

Figure 3. Effect Meditation CAINCO

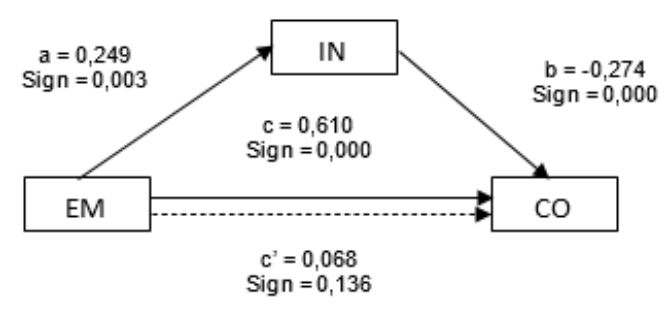

Figure 4. Effect Mediation EMINCO

\section{CONCLUSION}

After going through several research processes, this research concludes that the determinants of the high and low competitiveness of micro, small and medium enterprises in Aceh Province are most strongly influenced by the business management development program for MSME actors and workers related to product creation. In addition, the product innovation factor also plays a positive and significant role in the competitiveness of MSME businesses, including the role of mediating indirect relationships. Meanwhile, the capital capability factor was found to have a negative and insignificant effect in this study.

\section{ACKNOWLEDGMENT}

Thank's a lot to Radja Publika as the Head Officer of IJERLAS Journal who has facilitated the process of publishing this scientific article and also especially to LPPM Universitas Malikussaleh. Who is willing to cooperate in the process of publishing articles about Determinants Of Msme Competitiveness In Aceh Province with Contrck Number: 118/PPK-2/SPK-JL/2021 and Reference Code: 21.04.FEB.09 at 15th july 2021. 


\section{REFERENCES}

Abbas, D. (2018). Pengaruh modal usaha, orientasi pasar, dan orientasi kewirausahaan terhadap kinerja ukm kota makassar. Jurnal Manajemen, Ide, Inspirasi, 5(1), 95-111.

Adam, M., Ibrahim, M., Ikramuddin, \& Syahputra, H. (2020). The role of digital marketing platforms on supply chain management for customer satisfaction and loyalty in small and medium enterprises (SMEs) at Indonesia. International Journal of Supply Chain Management, 9(3), 1210-1220.

Adam, M., Ibrahim, M., Syahputra, H., \& Ikramuddin. (2020). The Role of Digital Marketing Platforms on Supply Chain Management for Customer Satisfaction and Loyalty in Small and Medium Enterprises ( SMEs ) at Indonesia. International Journal of Supply Chain Management, 9(3), 1210-1220.

Afraz, M. F., Bhatti, S. H., Ferraris, A., \& Couturier, J. (2021). The impact of supply chain innovation on competitive advantage in the construction industry: Evidence from a moderated multi-mediation model. Technological Forecasting and Social Change, 162(June 2020), 120370. https://doi.org/10.1016/j.techfore.2020.120370

Al-Abdallah, G. M., \& Al-Salim, M. I. (2021). Green product innovation and competitive advantage: an empirical study of chemical industrial plants in Jordanian qualified industrial zones. Benchmarking, 28(8), 2542-2560. https://doi.org/10.1108/BIJ-03-2020-0095

Al Hakim, H. ., Aminah, P. ., I, I., Milanie, F. ., \& Saifannur, A. S. (2021). JURIDICAL ANALYSIS OF RIGHTS REGISTRATION PROCESS ON LAND AND OWNERSHIP STATUS TO CONFIRM LEGAL ASSURANCE: STUDYRESEARCH IN THE AGENCY OFFICE NATIONAL LAND BATAM CITY. International Journal of Educational Review, Law And Social Sciences (IJERLAS), 1(1), 10-25. https://doi.org/10.54443/ijerlas.v1i1.7

Ali, G. A., Hilman, H., \& Gorondutse, A. H. (2020). Effect of entrepreneurial orientation, market orientation and total quality management on performance: Evidence from Saudi SMEs. Benchmarking, 27(4), 1503-1531. https://doi.org/10.1108/BIJ-08-2019-0391

Aprilia, D. S., \& Melati, I. S. (2021). Pengaruh Jumlah Tenaga Kerja, Modal Usaha dan Bauran Pemasaran Terhadap Keberhasilan Usaha UMKM Sentra Batik Kota Pekalongan. Journal of Economic Education and ..., 2(1), 81-94. Retrieved from http://ejournal.ivet.ac.id/index.php/jeee/article/view/1728

Ashoor, W. A. (2021). Transformational Leadership and Innovation for Competitive Advantage in Large Firms and SMEs. International Journal of $R \& D$ Innovation Strategy, 3(1), 1-12. https://doi.org/10.4018/ijrdis.20210101.oa2

Badan Pusat Statistik (BPS). (2020). Statistik Telekomunikasi Indonesia. ( dan P. Direktorat Statistik Keuangan, Teknologi Informasi, Ed.). Jakarta: Badan Pusat Statistik. https://doi.org/8305002

Baron, R. M., \& Kenny, D. a. (1986). The Moderator-Mediator Variable Distinction in Social The Moderator-Mediator Variable Distinction in Social Psychological Research: Conceptual, Strategic, and Statistical Considerations. Journal of Personality and Social Psychology, 51(6), 1173-1182. https://doi.org/10.1037/0022-3514.51.6.1173

CEOWORLD.Magazine's. (2021). World's Most Entrepreneurial Countries , 2021. Retrieved from https://ceoworld.biz/2021/01/03/worlds-most-entrepreneurial-countries-2021/

Christa, U. R., \& Kristinae, V. (2021). The effect of product innovation on business performance during covid 19 pandemic. Uncertain Supply Chain Management, 9(1), 151-158. https://doi.org/10.5267/j.uscm.2020.10.006

Dixon, A. O., \& Pusparini, E. S. (2020). The Role of Structural Empowerment and Innovative Behavior in Defining Business Process Innovation and Competitive Advantage to Cope with Industry 4.0. Advances in Economics, Business and Management Research, 160(Icbmr), 226-232. https://doi.org/10.2991/aebmr.k.201222.033

El Chaarani, H., Vrontis, P. D., El Nemar, S., \& El Abiad, Z. (2021). The impact of strategic competitive innovation on the financial performance of SMEs during COVID-19 pandemic 
period. Competitiveness Review: An International Business Journal, ahead-of-p(ahead-ofprint), 14-15. https://doi.org/10.1108/CR-02-2021-0024

Gjergji, R., Vena, L., Sciascia, S., \& Cortesi, A. (2021). The effects of environmental, social and governance disclosure on the cost of capital in small and medium enterprises: The role of family business status. Business Strategy and the Environment, 30(1), 683-693. https://doi.org/10.1002/bse.2647

Herman, \& Armadi, D. A. (2021). “ PROFESSIONAL EMPOWERMENT AND ORGANIZATIONAL COMMITMENT TO IMPROVE BUMDESA COMPETITIVENESS IN. Psychology and Education Journal, 58(2), 1-11. https://doi.org/10.17762/pae.v58i2.2375

Ikramuddin, Adam, M., Sofyan, H., \& Faisal. (2018). Determination of Brand Loyalty in Telecommunication Industry: a Literatur Review. International Journal of Engineering \& Technology, 7(3.30), 59-62. https://doi.org/10.14419/ijet.v7i3.30.18155

Joseph F. Hair, J., Black, W. C., Babin, B. J., \& Anderson, R. E. (2018). Multivariate Data Analysis. Cengage Learning, EMEA Cheriton House, North Way Andover, Hampshire, SP10 5BE United Kingdom Cengage. https://doi.org/10.1002/9781119409137.ch4

Junedi, J., \& Arumsari, M. D. (2021). Pengaruh Modal Usaha , Kualitas Produk , Jaringan Wirausaha Terhadap Kelangsungan Usaha UMKM Madu Sari Lanceng Pendahuluan. Jurnal Manajemen Strategik Kewirausahaan, 1(2), 175-184. https://doi.org/https://doi.org/10.37366/master.v1i2.223

Kholidah, N., \& Hakim, M. R. (2018). Peluang dan Tantangan Pengembangan Usaha Mikro Kecil Menengah (UMKM) Dari Berbagai Aspek Ekonomi. Jurnal Ilmiah Manajemen Dan Bisnis, 2(1), 181-197.

Lafuente, E., Szerb, L., \& Rideg, A. (2020). A system dynamics approach for assessing SMEs' competitiveness. Journal of Small Business and Enterprise Development, 27(4), 555-578. https://doi.org/10.1108/JSBED-06-2019-0204

Le, T. T., \& Ikram, M. (2021). Do Sustainability Innovation and Firm Competitiveness Help Improve Firm Performance? Evidence From the SME Sector in Vietnam. Sustainable Production and Consumption, November, 14-16. https://doi.org/10.1016/j.spc.2021.11.008

Malhotra, N. K., Lopes, E. L., \& Veiga, R. T. (2014). STRUCTURAL EQUATION MODELING WITH LISREL: AN INITIAL VISION. Revista Brasileira de Marketing, 13(2), 28-43. https://doi.org/10.5585/remark.v13i2.2698

Munifatik, Askandar, N. S., \& Mahsuni, W. A. (2018). PENGARUH MODAL, STRUKTUR PERSAINGAN , DAN PENDAPATAN TERHADAP INDEKS DAYA SAING UMKM KOTA BATU. E-JRA, 07(12), 43-55.

N Ntwiga, P., Muchara, M., \& Kiriria, P. (2021). The Influence of Employee Empowerment on Competitive Advantage in Hospitals within Nairobi, Kenya. East African Health Research Journal, 5(1), 26-35. https://doi.org/10.24248/eahrj.v5i1.648

Nyoman, S., Suryadinatha Oka, A., \& Mahaputr, I. I. R. (2017). Pemberdayaan usaha mikro kecil dan menengah (umkm) melalui program binaan di provinsi bali. Jurnal Ilmiah Manajemen Dan Bisnis Volume, 2(1).

Oláh, J., Virglerova, Z., Popp, J., Kliestikova, J., \& Kovács, S. (2019). The assessment of nonfinancial risk sources of SMES in the V4 countries and Serbia. Sustainability (Switzerland), 11(17), 1-19. https://doi.org/10.3390/su11174806

Omerzel, D. G., \& Jurdanab, D. S. (2016). The influence of intellectual capital on innovativeness and growth in tourism SMEs: Empirical evidence from Slovenia and Croatia. Economic Research-Ekonomska Istrazivanja , 29(1), 1075-1090. https://doi.org/10.1080/1331677X.2016.1211946

Purwati, A. A., Budiyanto, Suhermin, \& Hamzah, M. L. (2020). The effect of innovation capability on business performance: the role of social capital and entrepreneurial leadership on smes in indonesia. Accounting, 7(2), 323-330. https://doi.org/10.5267/j.ac.2020.11.021 
Puspaningrum, A. (2020). Market Orientation , Competitive Advantage and Marketing Performance of Small Medium Enterprises ( SMEs ). Journal of Economics, Business, and Accountancy Ventura, 23(1), 19-27.

Rajadurai, J., Zahari, A. R., Esa, E., Bathmanathan, V., \& Ishak, N. A. M. (2021). Investigating Green Marketing Orientation Practices among Green Small and Medium Enterprises. Journal of Asian Finance, Economics and Business, 8(1), 407-417. https://doi.org/10.13106/jafeb.2021.vol8.no1.407

Rasyid, H. Al, \& Indah, A. T. (2018). Pengaruh Inovasi Produk dan Harga Terhadap Keputusan Pembelian Sepeda Motor Yamaha di Kota Tangerang Selatan. Perspektif, XVI(1).

Ren, S., \& Song, Z. (2021). Intellectual capital and firm innovation: incentive effect and selection effect. Applied Economics Letters, 28(7), 617-623. https://doi.org/10.1080/13504851.2020.1767281

Ryu, D., Baek, K. H., \& Yoon, J. (2021). Open innovation with relational capital, technological innovation capital, and international performance in SMEs. Sustainability (Switzerland), 13(6), 1-13. https://doi.org/10.3390/su13063418

Sedyastuti, K. (2018). Analisis Pemberdayaan UMKM dan Peningkatan Daya Saing Dalam Kancah Pasar Global. Jurnal Inovasi Bisnis Dan Manajemen Indonesia, 2(1), 117-127.

Sulistyo, H., \& Ayuni, S. (2020). Competitive advantages of SMEs: The roles of innovation capability, entrepreneurial orientation, and social capital. Contaduria y Administracion, 65(1), 1-18. https://doi.org/10.22201/FCA.24488410E.2020.1983

Susana, E., Darsono, J., \& Andarwati, M. (2020). Implementation of the Empowerment Model For Small And Medium Enterprises Based On Regional Potentials And Market Oriented. IOSR Journal of Business and Management (IOSR-JBM), 22(9), 36-46. https://doi.org/10.9790/487X-2209053646

Winarti, E., Purnomo, D., \& Akhmad, J. (2019). ANALISIS FAKTOR-FAKTOR YANG MEMPENGARUHI DI PERKAMPUNGAN INDUSTRI KECIL ( PIK ). Jurnal Lentera Bisnis, 8(2).

Zhang, M., Fan, B., Zhang, N., Wang, W., \& Fan, W. (2021). Mining product innovation ideas from online reviews. Information Processing and Management, 58(1), 102389. https://doi.org/10.1016/j.ipm.2020.102389

Zuliyati. (2013). Implementasi Pengelolaan Modal Intelektual (Intellectual Capital) Untuk Menciptakan Daya Saing UMKM. Jurnal Dinamika Ekonomi \& Bisnis, 10(2), 105-114. 
Volume 1 No 2 (2021)

Determinants Of MSME Competitiveness In Aceh Province

Chairil Akhyar, Ikramuddin, Em. Yusuf Iis, Mariyudi 